\title{
THE VALUE ADDED STATEMENT: BASTION OF SOCIAL REPORTING OR DINOSAUR OF FINANCIAL REPORTING?
}

By

C.J. van Staden

\author{
Department of Accountancy and Business Law \\ College of Business \\ Massey University \\ Palmerston North \\ New Zealand
}


By

\author{
C. J. van Staden
}

Department of Accountancy and Business Law College of Business

Massey University

Palmerston North

New Zealand 


\title{
THE VALUE ADDED STATEMENT: BASTION OF SOCIAL REPORTING OR DINOSAUR OF FINANCIAL REPORTING?
}

\begin{abstract}
South Africa is at present experiencing the highest incidence of publication of the value added statement reported anywhere in the world to date. In addition research investigating the predictive ability of value added information has been conducted in the USA since 1990, even though the value added statement has not been published there. The research reported in this paper sets out to establish whether the value added statement is a disclosure worth considering by companies around the world, by investigating the South African experience with the value added statement.

The social accounting theories of organisational legitimacy and political costs were found to be best suited to explain why the value added statement is published. Surveys among the companies publishing the value added statement indicated that management had the employees in mind when they published this information. However, a survey among users has indicated that very little use has been made of the value added statement. The main reason for this seems to be that the unregulated nature of the value added statement allows for inconsistencies in disclosures, which eventually caused users to suspect bias in the reports. The USA evidence that the information has additional predictive power is not confirmed by a South African study, and is complicated by the limited additional information contained in the value added statement.
\end{abstract}

The South African experience with the value added statement does not make a convincing case for publication. Rather, it highlights the need for unbiased and verified social disclosures that will be useful to all the stakeholders of the company. In addition, it has implications for other voluntary social and environmental disclosures. 


\section{THE VALUE ADDED STATEMENT: BASTION OF SOCIAL REPORTING OR DINOSAUR OF FINANCIAL REPORTING?}

\section{INTRODUCTION AND MOTIVATION}

It is perhaps not widely known that the value added statement (VAS) is at present published voluntarily by more than 200 of the 400 companies listed in the industrial sector on the Johannesburg Stock Exchange, as part of their annual financial statements. This is the highest incidence of publication of such statements reported anywhere in the world to date, which makes South Africa a suitable place to investigate the continued publication of the VAS. Outside South Africa, the statement is not published to this extent at all, with United States companies not publishing the statement and the United Kingdom having several periods when the statement was published by up to $30 \%$ of the larger companies (Gray and Maunders, 1980). The VAS features in some evaluations of social disclosures like the corporate social reporting database project Gray et al., 1995). In addition, research has recently been conducted in the United States on the topic, with more than 10 papers being published since 1990 on the predictive and explanatory power of value added information.

The research reported in this paper sets out to establish whether the value added statement is a disclosure worth considering by companies around the world, by investigating the South African experience. To put the South African experience into proper perspective, reference is made to previous experience with the publication of the statement, the underlying theories and the political and socio-economic situation in South Africa. The views of users of financial reports, as established by a South African survey, are used to provide a practical perspective for the arguments.

As the predictive and explanatory power of value added information could indicate that it has decision usefulness with regards to the capital providers, this was also investigated with reference to the decision usefulness of social disclosures in general, and value added information in particular. A South African study examining the predictive and explanatory power of value added information is used to give a contrasting position to the studies done in the United States in this regard.

The paper begins with the theory and definition of value added, followed by a brief background to the publication of the VAS around the world and a summary of the research on value added statements. The reasons for publishing the VAS are then investigated, followed by the reasons for the trends observed in the United Kingdom (UK). Aspects that differentiate South Africa (SA) from other countries, which could help to explain the popularity of the statement in SA, are followed by research among the users of the statement. Market related arguments for publishing the statement are then investigated. In conclusion, the evidence is reviewed and the impact for other voluntary disclosures is briefly considered. 


\section{THE THEORY AND DEFINITION OF VALUE ADDED}

The concept of value added was initially used in 1790 in the first North American Census of Production (Gillchrist, 1970). Trenche Cox, a treasury official, whose techniques have since been adopted by most industrial nations in the calculation of Gross National Product (GNP), is regarded as the man responsible for realising that value added would avoid double counting. Value added has also been defined in the economic literature by Ruggles and Ruggles (1965). The VAS therefore, has a macro economic origin, in that the calculation of value added in the value added statement corresponds with the calculation of GNP, as well as economic significance.

Suojanen (1954) defined the firm as an enterprise or decision-making centre for the participants, that is the enterprise theory. Accountancy's role in this regard is to report the results to the various interested parties in ways they can understand best. Suojanen suggested the value added concept for income measurement, as a way for management to fulfil their accounting duty to the various interest groups by providing more information than was possible from the income statement and balance sheet. This makes him one of the first writers to use the value added concept in terms of accounting for the results of an enterprise.

Value added can be defined as the value created by the activities of a firm and its employees, i.e. sales less the cost of bought in goods and services. The value added statement (VAS) reports on the calculation of value added and its application among the stakeholders in the company. As such it introduces very little new information to that already contained in the income statement (salaries and wages used to be the only additional information), but it presents the information in a different and supposedly more understandable format.

\section{BACKGROUND TO THE PUBLICATION OF THE VALUE ADDED STATEMENT AND RESEARCH ON THE STATEMENT}

In the United Kingdom, early forms of the value added statement functioned as part of a worker participation orientation towards the management of economic performance. It was important during the economic crisis of the immediate post-war era, but it disappeared during the prosperous years of the 1950s and the 1960s, only to return when similar strategic postures were adopted towards the management of the economy in the mid-1970s (Burchell, Clubb and Hopwood, 1985).

According to Gray and Maunders (1980) the origins of the then recent interest in the United Kingdom in value added statements can be found in The Corporate Report (ASSC, 1975), which suggested the publication of a value added statement amongst other reforms. From 1977 onwards an increasing number of United Kingdom companies published the VAS, as has been established by various surveys of published financial statements (see for example 
Morley, 1978; Rutherford, 1978; and Gray and Maunders, 1980). In 1981 Burchell et al. predicted that the value added statement could lose its significance again when the sociopolitical landscape changed. The research of Burchell et al. (1985) indicated that the incidence of publication reached a climax in 1980, but started declining after that. In the United Kingdom there were, therefore, definite trends towards and away from the publication of value added statements.

A review by Gray and Maunders (1980) of the publication of the statement around the world indicated that a significant number of companies in the Netherlands, France and Germany provided value added data. They also noted growing instances of value added statements being disclosed in countries such as Denmark, Switzerland and Italy. An additional supportive influence in the European context was the interest of financial analysts in value added data, especially in France. No further reference to the publication of the statement in Europe could be traced in the literature. In the United States of America and Canada companies have not published value added statements at all.

Burritt and Clarke (1984) reported that the Australian approach to value added had been very cautious, showing nothing like the initial zeal in Britain. A few companies published value added statements (eight companies of the largest 100 in 1982, for example) as a regular supplement to the traditional accounts. Mathews and Perera (1996) reported that in New Zealand very few companies published a VAS as part of their financial statements.

In South Africa the interest in value added statements started with the publication of The Corporate Report in 1975. This led to six companies in the top 100 publishing value added statements in 1977 (SAICA, 1981). However, unlike the situation in the United Kingdom, where the incidence of publication has fallen since 1980, the incidence of South African companies publishing the value added statement has increased with a total of 74 companies in the top 100 producing a statement in 1990 (Stainbank, 1992). De Villiers (1997) reported that $34 \%$ of the 606 companies listed on the JSE published a value added statement in 1996. In 1997, more than 200 companies in the industrial sector of the Johannesburg Stock Exchange (JSE) published a value added statement as part of their annual financial statements.

A review of the literature on the subject has revealed more than 150 articles, books and research reports published on the subject since 1954, when Soujanen wrote the first article linking value added with accounting. The timing of these publications follows the trend of the publication of the statement as observed in the UK, with more than $80 \%$ of the literature published between 1975 and 1990. The research published concentrated mainly on the calculation of value added, the publication of value added statements, and the inconsistencies 
observed in this process. Research on the topic declined significantly when UK companies stopped publishing the statement.

Interest in the VAS has increased in recent years in the USA and SA. In the USA, ten research studies on the subject, dealing mainly with the predictive and explanatory power of value added information, have been published since 1990. This research calculates value added from the information published by the companies Riahi-Belkaoui, 1996a). In South Africa research on the usefulness of the value added statement has been published during 1998 and 1999.

\section{REASONS FOR THE PUBLICATION OF THE VALUE ADDED STATEMENT}

The VAS is regarded as a social disclosure, and therefore socially related arguments can be used to establish a theoretical case for publication. According to Mathews and Perera (1996) and Gray et al. (1995), these theories include organisational legitimacy, social contract and political cost theory. The concept of organisational legitimacy suggests that management can influence the perception that the stakeholders have of the organisation, and in this way obtain the support of those stakeholders without which it might be difficult for the company to continue to operate. The social contract of business with society is based on the premise that society provides corporations with their legal standing and attributes and the authority to own and use natural resources and to hire employees and that a social contract is therefore implied. Political cost theory is based on the premise that companies do have political visibility and that companies have an incentive to use accounting methods and disclosures to influence their political visibility.

The social theories therefore indicate that management has an obligation and an interest to report to the other stakeholders. Although most of the accounting frameworks suggest this (for example the International Framework IAS, 1988) they do not require any financial statement or disclosures that will meet the needs of stakeholders other than the financial participants and these disclosures have therefore remained voluntary. As value added statements in practice indicate how value added was allocated between various stakeholders, they might be considered to be interested in the value added statement. The stakeholders specifically addressed in the VAS are the employees, the capital providers and the government.

Most of the literature on the value added statement indicates that it was aimed primarily at the employees. This was anticipated by the Corporate Report, published by the Accounting Standards Steering Committee (ASSC) in 1975, when it described the value added statement as the "simplest and most immediate way of putting profit into proper perspective vis-à-vis the whole enterprise as a collective effort by capital, management and employees ..." This move away from reporting on profits only, is supposed to make the financial information more 
relevant and understandable to the other stakeholders. The VAS therefore became known as a disclosure aimed at uninitiated and unsophisticated users of financial information.

In addition, a number of surveys have been conducted among companies publishing the statement (for example, Purdy, 1981; Joubert, 1991; and Stainbank, 1992) These surveys found little evidence of actual use. The companies used the statement mostly for employee communication and wage negotiations. A survey was conducted during 1998 among SA companies to establish why they are publishing the VAS. The companies were selected on a random basis and 94 responses were received. The following are the five reasons given by most companies, in order of importance:

- To be used in corporate communication with employees

- To earn points in annual financial statement awards

- To indicate social responsibility on the part of the company

- To facilitate wage negotiations and collective bargaining

- To condition employee expectations

Therefore, it would appear that the social theories require management to report to the other stakeholders and that management have these stakeholders, and particularly the employees, in mind when they publish the VAS. The VAS is also an ideal vehicle to change perceptions of the company as it is unregulated and normally not audited, and can be used by management to condition expectations. Unfortunately, this aspect has eventually led users to mistrust the statement (for example, it almost always indicates that the labour component takes most of the value added (Hird, 1983)).

\section{REASONS FOR THE UNITED KINGDOM TRENDS}

The value added statement seems to present an organisation that is not driven by profit motives but by the common good of the participants. The enterprise theory as expressed by Soujanen (1954) saw the company as a decision-making centre where decisions affecting various interested parties are made. The VAS could therefore be regarded as a statement that recognises the importance of the other stakeholders to the organisation. Burchell et al. (1985) confirmed this by indicating that value added was seen as a performance criterion that put employees on a par with other interests in the enterprise. The fact that the VAS often indicated that labour made a huge contribution to value added could have been part of the reason why it became unpopular in the UK. For example, Seal $(1987$, p.157) contended that the trend away from value added statements in the 1980s in the United Kingdom is;

"not simply a function of its marginality ... or its ambiguity. Rather the mode of thinking introduced by the value added approach is potentially a barrier to the sort of fundamental restructuring that capitalism periodically requires and that has been so much in evidence in the United Kingdom in the 1980s". 
Hird (1983, p.143) put this much more bluntly when he indicated that;

"[s]ince the election of the Tories in 1979 many British companies have succeeded in persuading workers to do as they are told by rather rougher methods than the publication of value added statements, such as closures and confrontation".

Burchell et al. (1985) indicated that the significance of value added varied with shifts in the socio-political landscape. When different policies were introduced in the UK, the functioning of value added in social relations declined due to its technical marginality (limited information content). Deegan and Halam (1991) found that management might prepare and present value added statements as a means of reducing the political costs imposed by the employees of the company, their related unions and the government.

The UK experience seems to support the political cost and organisational legitimacy theories as explanations for the trends in the publication of the VAS. If there are no legitimacy threats and companies are not faced with political costs, the UK experience indicates that companies will stop publishing the statement. Mathews and Perera (1996) indicated that it is difficult to predict the future publication of value added statements and that they may become important again under the appropriate social and economic conditions.

\section{THE SOUTH AFRICAN SITUATION}

The following differentiate SA from other countries and could have contributed to the high level of publication of the VAS in SA at present:

- $\quad S A$ is a developing country.

- SA has strong labour unions and labour laws protecting employees.

- $S A$ is going through an economic transition following its political transition to a democracy.

- SA companies are still trying to get rid of the stigma associated with apartheid and publishing a VAS can cause companies to appear more socially concerned than what they really are'.

- SA companies have one of the biggest gaps between highest and lowest earners in the world and are experiencing increasing pressure to reduce the gap.

The current socio-political climate in South Africa, where low economic growth and high unemployment (30-40\%) coupled with a strong alliance between labour and the government do not favour the interests of capital, has been anticipated since the early 1990s. South African companies therefore faced a high political cost. After the democratic elections in SA in 1994, the government was controlled democratically but wealth still remained in the hands of a limited number of capitalists. This situation is still the same, although empowerment companies have been formed and are advancing investment by non-traditional investors and 
trade unions on the JSE. It will however take a long time before previously disadvantaged groups become shareholders in South African companies to any significant extent.

SA has strong labour unions that are very effective in instituting strike action to meet their demands. Employees are protected by very favourable labour laws, which makes it difficult to reduce employee numbers without exploring all other alternatives in consultation with the unions involved. It is indicative of the power of the unions and the futility of trying to influence their actions by publishing a VAS, that SA has experienced the highest levels of industrial strikes in its history since 1994, despite the high levels of publication of the VAS.

It would appear that the high incidence of publication in South Africa can be explained with reference to the legitimacy threats as described in the preceding paragraphs. According to Lindblom (1994) organisations may employ several legitimation strategies when they are faced with legitimacy threats. These include changing the stakeholders' perceptions of the event and distracting attention away from the issues of concern. The VAS seems ideal for these purposes in that it removes the attention from profits to the employee's share of value added and the unregulated nature of the statement allows for using it to change perceptions regarding the return to the capital providers. In addition, by lumping all employees together in one category, management does not have to account for the differences between the highest and lowest earners.

\section{RESEARCH AMONGST USERS}

Very little research was found on the usefulness of the VAS, as indicated by use. It is surprising that after value added statements have been published for more than 25 years, the literature on the subject contains almost no evidence of research on the usefulness of the statement. This can perhaps be an indication that the VAS is not useful, but it is more likely an indication that accounting researchers preferred doing empirical research on financial information rather than surveys among users during this period.

In a South African study, Van Staden (1998) investigated the usefulness of the VAS using a questionnaire survey among the external users of financial information. Most of the users of financial statements, as identified by authoritative documents around the world, were included and eight user groups (including employees, the public and government) defined. The questionnaire was developed from the world-wide literature on the value added statement as published over the last 40 years. It aimed to determine the extent to which users of financial statements use the VAS, have done so in the past, or will do so in future. To establish this, 45 potential uses of the value added statement as found in the literature, were used. Likewise, the questionnaire used 28 potential shortcomings of the statement to establish if this

prevented users from using the statement. The questionnaire also included questions on the future use of the statement and the decisions influenced by information in the statement. 
The response rate for each user group was above $15 \%$ and the average above $20 \%$. This was regarded as sufficient for a postal survey. A surprising finding from the survey was that the employee user group, represented by the trade unions, makes almost no use of the statement. Because of a limited response from the trade unions to the postal survey, the unions were subsequently visited and interviewed. Unions representing $60 \%$ of the membership of the most important three trade union groupings in SA were visited and the finding of no use amongst the biggest unions representing most of the workers in SA, is quite significant. This is despite the fact that most of them use the financial information reported by the companies employing their members.

The main reason for this lack of use appears to be the major shortcomings experienced by the users when using the statement. A strong inverse correlation ( $R$ of -0.61$)$ was observed between the shortcomings experienced by a specific user group and the use made of the value added information by that group. Another reason was that the value added statement seemed to almost always indicate that the employees got most of the value added (and that by implication they shouldn't get more - Hird 1983). Respondents also had problems with value added as a measure for productivity and benchmarking in this area.

The shortcomings experienced by users related mainly to the inconsistencies found in the calculation of value added and disclosures in the VAS, which stem directly from the lack of statutory requirements for production of the VAS. These inconsistencies made the statement confusing, non-comparable and unverifiable. The existence of these inconsistencies was also confirmed by the many research studies examining the present and past value added reporting formats which have been undertaken (see for example Gray and Maunders, 1980; Renshall, Allan and Nicholson, 1979; and Stainbank, 1992). These studies have found that the accounting practices used in the statement are diverse. The main areas of inconsistencies include, but are not limited to, the following:

- the treatment of depreciation resulting in gross and net value added

- the treatment of taxes like pay-as-you-earn, fringe benefits and other benefits in the employees' share of value added

- the timing of recognition of value added - production or sales

- the treatment of taxes such as VAT/GST and deferred tax

- the treatment of non-operating items.

Although most of the literature on the value added statement dealt with these aspects, the inconsistencies in the VAS continues (Stainbank, 1997). Even though there were efforts to effect standardisation of the value added statement by way of statutory requirements, the statement is at present still a voluntary disclosure. Reasons why statutory requirements for 
the value added statement have not developed have been explored (Van Staden, 1999b; and Burritt and Clarke, 1984).

It has already been indicated that the total salaries and wage cost of the company is often the only new information disclosed in the value added statement. In comparison to some of the more traditional financial statements, like the income statement and the balance sheet, the VAS introduces a new perspective rather than a lot of new information. The results of the survey indicated that the users, particularly the employees, regarded the inconsistencies in the disclosures as offsetting the benefits of the another perspective, and rather relied on the information as contained in the traditional financial statements which is governed by generally accepted accounting practice (GAAP) and independently verified. As far as salaries and wages information goes, the unions overwhelmingly indicated that an aggregate figure for the whole company was basically meaningless and that they needed the figure to be broken down by level of employment, including the number of employees per level. This kind of breakdown was never included in value added statements making the unions even less inclined to use the information.

Even though the socially related arguments could be used to explain why management should publish the value added statement, the finding of almost no use among the stakeholders in general, and the employees in particular, seems to indicate that there is an expectation gap between the reasons for publication and the actual use of the information.

\section{MARKET RELATED ARGUMENTS}

Based on a normative approach of profit maximisation as the primary aim of an organisation, and the decision usefulness approach to the publication of financial information, annual financial statements have been primarily aimed at the financial participants in the company, being the shareholders and the creditors. Even recent accounting frameworks (for example the International Framework) have not had a significant impact on this and the other stakeholders have been largely disregarded (see also Mathews, 1997). The publication of the value added statement could therefore be motivated if it has additive or predictive value for the financial participants.

Although many studies have investigated the link between social disclosures and market indicators, the results have been conflicting. This is perhaps not surprising considering the difficulty in explaining investor reactions using economic theory. On the one hand Friedman (1970) argued that the "social responsibility of business is to increase its profits" and warned that social expenditure that reduced profits could have a negative impact on investors. In contrast, it has been argued that investors will reward firms engaged in social activities by investing in them even at the risk of lower returns (Milne and Chan, 1999). It is therefore 
difficult to form an expectation of investor reaction, as different investors will have different expectations.

Mathews and Perera (1996) reported on studies done in the period from 1971-1984. These studies all attempted to relate some measure of social responsibility to measures of market performance. The studies looked at measures ranging from subjective indicators of social performance to objective indicators as reported by outside parties. They concluded that "although the findings from a number of studies are conflicting, it may be argued that the overall weight lies towards a view that the disclosure of non-traditional information does have utility for shareholders and the security market. However there are other, perhaps stronger, arguments in favour of social accounting disclosures." Gray et al. (1995) found from studies done during the period 1979-1990 that corporate social reporting (CSR) disclosures did not appear to be related to profitability in the same period, but might be related to lagged profits. They also reported on decision-usefulness studies done on CSR information during the same period and concluded that despite some studies indicating that CSR information is not useless, the decision usefulness approach to investigating CSR has been largely unsatisfactory. Milne and Chan (1999) confirmed this by stating that little is actually known about the investment decision impact, or for that matter any decision impact, of social disclosures. They found from a review of the research that there was no consistency in the market reaction studies and that it was doubtful whether these studies provide strong support for the proposition that social information is useful for making investment decisions.

Considering value added statements specifically, value added information is expected to have an impact on the external indicators of the company as it indicates how the value added of the company is allocated between the various stakeholders. As the shareholders will perceive the other stakeholders to be in competition with them for a share of value added, they can be expected to react negatively if the other stakeholders get too much of the value added. If, on the other hand, the value added statement indicates that any of the stakeholders has not received a fair return, it could also impact on the future share price (Gray and Maunders, 1980). Although this is perhaps not the strongest argument for decision usefulness, it has already led to a number of research studies in this regard.

From 1990 to 1996 Riahi-Belkaoui conducted a series of studies investigating the link between value added information and market indicators in the USA. With Karpik (1990) he established that value added accounting information could supply considerable explanatory power of market risk beyond that provided by earnings or cash flow measures, especially at the individual firm level. In 1993 he established that value added information can supply some explanatory power of security returns beyond that provided by earnings or cash flow measures. He did a similar study with Picur (1994) in which they concluded that value added information can supply important explanatory power of security valuation beyond that 
provided by earnings. In 1996 (1996a) he found that value added information published concurrently with earnings did have additive information content. In the same year, (1996b) he found that value added-returns relationships offered better explanatory power than the earnings-returns relationships, when the relationships were expressed by a non-linear, convex-concave function. In 1996 (1996a) he also found that productivity (as measured by value added) did not provide information about future profitability incremental to that provided by current profitability. This finding seems to be surprising considering his earlier findings.

In other studies in this area, Boshoff (1996) found that value added information did not have predictive power with regards to share price and price earnings ratio. Bao and Bao (1996) examined the time series properties of value added as well as the prediction accuracy of the value added series. They found that the random walk model, which indicates that the effects of the factors that affect value added, and the direction of the changes, are not predictable, best fitted the value added measures and was consistent with that of annual earnings and share prices.

In a South African study Van Staden (1999a) examined the predictive and explanatory power of value added information in comparison to earnings for three external indicators over a fiveyear period. The external indicators were share price, price-earnings ratio and altmans $z$ chosen with regards to importance, risk and future success or failure. All companies that published a value added statement for three of the five years were included in the sample. As already indicated, this represented a significant percentage of companies listed on the JSE (more than $30 \%$ ). The aim of the study was to establish if value added had additional predictive and explanatory power beyond that provided by earnings, which is already a disclosure requirement for companies. Value added for the year as well as changes in value added was used in the statistical analysis. As value added as published by the companies is not calculated and reported in a consistent way, gross and net value added were calculated for each company in a standard way and in addition value added as published by the company was also used. This gave rise to three value added measures which was each tested individually against the external indicators.

The study found meaningful correlation and regression between the value added measures and share price, but it was not more significant than the correlation between earnings and share price. As multicollinearity between the value added measures and earnings was observed, they cannot be used in combination to improve on the predictive power of earnings. The analysis of the empirical data of the South African companies therefore indicated that value added information did not have significant predictive and explanatory power beyond that of earnings for the three selected external indicators. 
In evaluating the research as reported, some factors limiting the evidence should be kept in mind (see also Van Staden and Vorster, 1998):

- From the literature on the subject it is evident that the VAS is not standardised and therefore the differences in calculation could lead to different results when testing against external indicators.

- In the USA the VAS is not published and the studies done by Riahi-Belkaoui calculates value added from publicly available data.

- The samples used had either not been large enough (with the possible exception of the SA study which included $30 \%$ of all listed companies) or not been statistically selected, which could have an impact on the generalisability of the results. The companies included in the samples were basically self selected, being those companies that published the VAS or enough information to calculate value added.

- The additional information content of value added is limited, being salaries and wages information. Although this information might be useful, it is doubtful whether the inclusion of salaries and wages information should make a substantial difference to the predictive and explanatory power of financial information. Also, salaries and wages information has subsequently become a requirement of the international accounting standard on the presentation of financial statements (IAS1, 1997) and should be adopted by most countries (SA has already adopted it). This will have the effect that the VAS will contain no information additional to that published in the income statement.

From the research carried out in this area it is clear that there are, on the one hand, some conflicting findings with regards to the link between social disclosures in general and value added information in particular and external measures of market performance. On the other hand, it would appear that value added does not provide information relating to market indicators that is additive to that of earnings. This limits the usefulness of value added information for predictive and explanatory purposes. The limited information content of value added is probably the main reason for this and it would be fair to conclude that the publication of the value added statement is not expected to have a significant impact on the external market indicators of the company. Decision usefulness to the financial participants can therefore not be used to motivate the publication of the value added statement.

\section{CONCLUSION}

The research indicates that social accounting theories can best be used to motivate the publication of the value added statement. This is confirmed by the UK experience during the 1970/80s. The current socio-political situation in South Africa warrants this and a logical conclusion would be that this explains the current high levels of publication in SA. However, the inconsistencies found in the disclosures, which have led users to suspect bias in unregulated and unverified reporting, and the limited information content of the disclosures, have caused the targeted users (particularly employees) not to make significant use of the 
VAS. This in itself is probably reason enough to question the continued publication of the statement. Management are either not aware that the users of financial statements are not finding the VAS useful, or they are aware and continue to publish the statement nevertheless. Even though the VAS does have an attraction in that it can be used to change perceptions of the company, the reason for publication is not clear if it is not being used.

The market related arguments do not seem to be useful in explaining why the VAS should be published, despite the current interest in research in this area in the USA. The SA evidence seems to contradict the US evidence (where the statement was not published) with regards to the predictive and explanatory power of the information. Despite the results of research published since 1990 in the USA, and suggestions by the American Accounting Association (AAA, 1990) that publication should be considered, US companies have not included value added statements in their financial reports.

The South African experience with the VAS does not make a convincing case for the publication of the value added statement. Rather it highlights the need for unbiased and verified social disclosures that will be useful to all the stakeholders of the company.

The impact of the experience with the VAS for voluntary disclosures in general is that the diversity allowed by voluntary disclosures might lead to inconsistencies, which eventually impact on the usefulness of the disclosures. With regards to social and environmental disclosures, the findings that most social disclosures by companies tend to be narrative (Hackston and Milne, 1996) and that most social disclosures are of good news rather than bad (or neutral) (see for example Hackston \& Milne, 1996; and De Villiers, 1999) indicate that the quality of the information and the usefulness of the information could be difficult to determine. 


\section{REFERENCES}

AAA. (1990). Committee on Accounting and Auditing Measurement - Report 1989-90. American Accounting Association.

ASSC. (1975). The Corporate Report. Accounting Standards Steering Committee, The Institute of Chartered Accountants in England and Wales: London.

Bao, B. and D. Bao. (1996). The Time Series Behavior and Predictive-Ability Results of Annual Value Added Data. Journal of Business Finance and Accounting, April 1996, 449460.

Boshoff, A. (1996). "Die Voorspellingswaarde van die Staat van Toegevoegde Waarde van Geselekteerde Suid-Afrikaanse Genoteerde Maatskappye". M Com Dissertation, Pretoria University: Pretoria.

Burchell, S., C. Clubb, and A.G. Hopwood. (1985). Accounting in its Social Context: Towards a history of value added in the United Kingdom. Accounting. Organizations and Society, 10(4), 381-413.

Burchell, S., C. Clubb, and A.G. Hopwood. (1981). 'A message from Mars' -and other reminiscences from the past. Accountancy, October 1981, 96-100.

Burritt, R.L. and F. Clarke. (1984). What are the prospects for corporate value added statements in Australia? The Chartered Accountant in Australia, May 1984, 36-39.

Deegan, C. and A. Hallam. (1991). The Voluntary Presentation of Value Added Statements in Australia: A Political Cost Perspective. Accounting and Finance, June 1991, 1-21.

De Villiers, C.J. (1999). Corporate Social Reporting in South Africa: signs of a pygmy awakening? Social and Environmental Accounting, 19(2), 5-7.

De Villiers, C.J. (1997). Employee Reporting in South Africa - Fourth Edition. University of Pretoria: Pretoria.

Evraert, S. and A. Riahi-Belkaoui. (1998), Usefulness of Value Added Reporting : A Review and Synthesis of the Literature. Managerial Finance, 24(11), 1-15.

Friedman, M. (1970). The Social Responsibility of Business is to increase its profits, The New York Times Magazine, 13 September 1970, 32-37.

Gillchrist, R.R. (1970). Company Appraisal and Control by Added Value Analysis. Certified Accountants Journal, October 1970, 573-580.

Gray, S.J. and K.T. Maunders. (1980). Value Added Reporting: Uses and Measurement. The Association of Certified Accountants: London.

Gray, R., R. Kouhy, and S.Lavers. (1995). Corporate social and environmental reporting - A review of the literature and a longitudinal study of UK disclosure. Accounting. Auditing \& Accountability Journal, $8(2)$, 47-77.

Hackston, D. and M.J. Milne. (1996). Some determinants of social end environmental disclosures in New Zealand companies. Accounting. Auditing \& Accountability Journal, 9(1), 77-108.

Hird, C. (1983). Challenging the Figures - a guide to company finance and accounts. Pluto Press: London.

IAS1. (1997). Presentation of Financial Statements. International Accounting Standard, International Accounting Standards Committee: London.

IAS. (1988). Framework for the Preparation and Presentation of Financial Statements. International Accounting Standards Committee: London.

Joubert, D.S. (1991). "'n Ondersoek na die samestelling en gebruikswaarde van die staat van toegevoegede waarde as komponent van die finansiele verslagdoening in die RSA". M Com Dissertation, VISTA University: Pretoria.

Karpik, P. and A. Belkaoui ${ }^{a}$. (1990). The Relative Relationship Between Systematic Risk and Value Added Variables. Journal of International Financial Management and Accounting, 1 (3), 259-276.

Lindblom, C.K. (1994). The implications of organizational legitimicy for corporate social performance and disclosure. Paper presented at the Critical Perspectives on Accounting Conference: New York.

Mathews, M.R. (1997). Towards a Mega-Theory of Accounting. Asia-Pacific Journal of Accounting, 4(2), 273-289.

Mathews, M.R. and M.H.B. Perera. (1996). Accounting theory and development $\left(3^{\text {rd }}\right.$ Ed). Nelson: Melbourne.

${ }^{a}$ Riahi-Belkaoui initially published under the name "Belkaoui" and from 1991 onwards under the name "RiahiBelkaoui". 
Milne, M.J. and C.C.C. Chan. (1999). Narrative Corporate Social Disclosures: How much of a difference do they make to investment decision-making? The British Accounting Review, 31(4), 439-457.

Morley, M.F. (1978). The Value Added Statement - A review of its use in corporate reports. The Institute of Chartered Accountants of Scotland, Gee \& Co Publishers Ltd: London.

Purdy, D.E. (1981) The value added statement: the case is not yet proven. Accountancy, September 1981, 113-114.

Renshall, M., R. Allan, and K. Nicholson. (1979). Added Value in External Financial Reporting. The Institute of Chartered Accountants in England and Wales: London.

Riahi-Belkaoui, A. (1996a). Performance Results in Value Added Reporting. Quorum Books: Westport, Connecticut.

Riahi-Belkaoui, A. (1996b). Earnings-Returns Relation Versus Net-Value-Added-Returns Relation: The Case for a Nonlinear Specification. Advances in Quantitative Analysis of Finance and Accounting, 4, 175-185.

Riahi-Belkaoui, A. and R.D. Picur. (1994). Explaining Market Returns: Earnings Versus Value Added Data. Managerial Finance, $\underline{20}(9)$, 44-55.

Riahi-Belkaoui, A. (1993). The Information Content of Value Added, Earnings, and Cash Flow: US Evidence. International Journal of Accountancy, 28, 140-146.

Riahi-Belkaoui, A. (1992). Value Added Reporting - Lessons for the United States. Quorum Books: Westport, Connecticut.

Ruggles, R. and N.D. Ruggles. (1965). National Income Accounts and Income Analysis. McGraw-Hill: New York.

Rutherford, B.A. (1978). Examining some value added statements. Accountancy, July 1978, 48-52.

SAICA. (1981). A Survey of Financial Reporting in South Africa. The South African Institute of Chartered Accountants: Johannesburg.

Seal, W.B. (1987). Value added and the theory of the firm: On mirages and the fallacy of decomposition. British Accounting Review, August 1987, 145-159.

Stainbank, L.J. (1997). Value added reporting in South Africa: current disclosure patterns. South African Journal of Accounting Research, 11(2), 69-91.

Stainbank, L.J. (1992). Value added reporting in South Africa. De Ratione, $\underline{6}(1), 43-58$.

Suojanen, W.W. (1954). Accounting Theory and the Large Corporation. Accounting Review, July 1954, 391-398.

Van Staden, C.J. (1999a). Aspects of the predictive and explanatory power of value added information in South Africa. South African Journal of Accounting Research, 13(2), 53-75.

Van Staden, C.J. (1999b). Revisiting the value added statement: a case for the formulation of statutory requirements for financial reporting. Meditari, 7, 257-275.

Van Staden C.J. (1998). The usefulness of the Value Added Statement in South Africa. Managerial Finance, 24(11), 44-59.

Van Staden, C.J. and Q. Vorster. (1998). The Usefulness of the Value Added Statement: a Review of the Literature. Meditari, $\underline{6}, 337-351$.

Wray, Q. (2000). Business spends R4bn+ a year on CSI. NetAssets News, 26/1/2000.

\footnotetext{
${ }^{1}$ A recent report by the SA Foundation based on research done by the Centre for Development and Enterprise indicates from a study of the 220 largest private organisations in SA that the corporates spend $1.3 \%$ of after tax profits on corporate social investment (CSI). While this is roughly equivalent to the USA and Canada, it is relatively minor compared to the total flow of resources from business to society. They indicate that for every R100 of after tax profits, the major corporates paid out R280 on salaries and wages, R69 in taxes, R13 on training and only R1.30 on CSI (Wray 2000). This might be an additional motivation for the publication of the VAS as the VAS indicates the flow of resources to society in that it has categories for salaries and wages (normally including training) and interactions with the government.
} 


\section{The value added statement: bastion of} social reporting or dinosaur of financial reporting?

van Staden, C. J.

2001

http://hdl.handle.net/10179/2543

22/04/2023 - Downloaded from MASSEY RESEARCH ONLINE 